J Chron Dis 1977, Vol. 30, pp. 225-245. Pergamon Press. Printed in Great Britain

\title{
EARLY LIFE SOCIAL INCONGRUITIES, HEALTH RISK FACTORS AND CHRONIC DISEASE*
}

\author{
Helen low Metzner, Ernest Harburg $†$ and Donald E. Lamphiear \\ Department of Epidemiology, University of Michigan, Ann Arbor, Michigan
}

(Received 12 February 1976)

\begin{abstract}
This study tested specific hypotheses concerned with the relationships between three early life stress variables occurring between 0 and $16 \mathrm{yr}$ of age and a variety of adult health status measures ascertained some $20-60 \mathrm{yr}$ later in a $40 \%$ sample of the Tecumsch Community Health Study population 35-69 yr of agc. The hypotheses stated that each of the following characteristics, relatively greater residential geographic mobility during childhood, being deprived of one or both natural parents for one or more years during this early formative period, and experiencing parental status incongruence, would be associated with higher levels of nine risk factors, greater prevalence of five chronic diseases, and a greater rate of mortality. The risk factors were systolic and diastolic blood pressure, blood glucose level, serum cholesterol, serum uric acid, the F.E.V.1.0 measure of lung function; adiposity, number of cigarettes smoked currently, and amount of aicohol consumed currently. The chronic conditions were CHD, hypertension, diabetes, chronic bronchitis and asthma. Also measured were the aggregation of these chronic conditions and whether or not the respondents ever smoked cigarettes or drank alcohol.

Five mobility measures and an index were developed. As predicted, in general, significant relationships were found among women between the five separate mobility variables and the health measures. Specifically, all five separate measures of mobility were related to CHD among older women, and most were related to cigarette smoking and alcohol consumption among all women. Various of the five mobility measures were related to various other specific health measures. In general, mobility was not related to the health measures studied among men. The hypotheses concerning parental deprivation and parental status incongruency were not substantiated by the data.
\end{abstract}

\section{INTRODUCTION}

THE AIM of this research was to test the general hypothesis that social incongruities experienced in early life are associated with sustained health impairment which can be detected much later in life. It was assumed that social incongruities found frequently in ordinary early life situations and experienced over a long term can induce chronic stress and morbid sequelae [1]. Three specific kinds of social incongruities experienced during childhood, assumed to place extraordinary adaptive demands on the children concerned, and eighteen measures of adult health status

\footnotetext{
*Supported in part by the Center for Research in Diseases of the Heart, Circulation and Related Disorders, University of Michigan, under Program Project Grant Number HL 09814 from the National Heart and Lung Institute and Grant MH 25280 from the National Institute of Mental Health and by the Fannie E. Rippel Foundation.

†Departments of Psychology and Epidemiology. University of Michigan; Director, Program for Urban Health Research.
} 
were studied. The three kinds of social incongruities were (1) geographic residential mobility from birth to $16 \mathrm{yr}$ of age, (2) parental deprivation, as defined by the absence of one or both natural parents during this same age period, and (3) parental status incongruity, as defined by a difference in parents' education level or a disparity between parental education level and the father's occupational status level. The multiple outcome measures of adult health status were nine health risk factors, five chronic disease conditions, a combination of these conditions, and mortality during a 5-yr followup period.

The social incongruities selected for study share the traits that they are not unusual but the children experiencing them are likely to be regarded as different by the people around them outside the home. They are the 'new' children; the children without a 'real' father or mother; those whose parents are too educated or not enough educated. Also within the home, these situations present exceptional demands. For those who have high residential mobility, there are the strains of the moving process itself, the adaptation to a new physical environment and to the changes in family routine associated with a change in the father's job. For those who are deprived of one or both parents, there are the problems of the one-parent or step- or foster-parent family. For those who have parental status incongruency, there are the problems of the parents having conflicting expectations of behavior relating to the differences in social status.

For several years, health professionals and a large proportion of the non-professional public have expressed a steady level of interest in the question of how ordinary every day events and situations of life experienced by the 'normal' or 'average' individual relate to personal health status. Ample evidence of professional interest is provided by several comprehensive reviews of the literature concerned with cardiovascular disease and psychosocial factors [2-8] and by conferences focused on psychosocial factors and health $[9,10]$. Research into this question has utilized indicators of health status ranging from single measures of physiological functioning such as blood pressure, serum cholesterol level and weight to physicians' diagnosis of diseases such as coronary heart disease (CHD) and rheumatoid arthritis and to individual's reports of illness. Usually the separate studies concentrate on relating a small set of psychosocial factors to a single measure of poor health such as CHD or hypertension or to such a measure and its acknowledged physiological risk factors. One basis for this kind of study design is the hypothesis that certain diseases have strong psychosomatic components and there are specific psychosocial factors associated with each of these diseases. A theoretical discussion of one aspect of this view has recently been published by Bahnson [11]. This kind of research is exemplified by the work of Rosenman, Friedman and associates relating CHD and Type A behavior $[12,13]$. Other researchers have examined the relationships between a broad range of illnesses and physiological measures and a variety of psychosocial factors [14]. Of late there has been much interest in pursuing this kind of inquiry using the life crises concept as the unifying theme for many psychosocial factors $[15,16]$. The theoretical merits of relating a broad range of health measures to a variety of psychosocial factors have been discussed by Syme and Cassel $[1,17]$.

Consonant with the ideas expressed by Syme and Cassel, this research was an investigation of the relationships among three kinds of not unusual early life social 
events and situations and a number of indicators of current adult health status as ascertained in the middle and later periods of life. A set of specific hypotheses was tested relating the defined early events and social situations to the set of designated chronic diseases and conditions and their predisposing risk factors.

\section{METHOD}

This research project analyzed a subset of data from the Tecumseh Community Health Study, a longitudinal, epidemiological study of an entire community of about 10,000 persons primarily oriented towards finding precursors to coronary heart disease, hypertension, diabetes, chronic bronchitis, asthma, hay fever and arthritis. The study has been described in detail in several publications $[18,19]$. Briefly, there were three major data collections involving health questionnaires administered in the home by trained interviewers and physical examinations in the study clinic. The clinic procedures included physiologic measurements, collections of blood and urine samples and examinations by physicians from the University of Michigan. All residents of the community were eligible to be included in the first two major data collections of 1959-1960 and 1962-1965 and about $85 \%$ participated. The cohort of those previously examined were included in the third major collection of 1967-1969. Between 1957 and 1972 when the first and last sizeable field investigations were made, there were several smaller studies that either involved samples of the whole study population or collected more limited kinds of interview or physical examination information.

\section{THE SAMPLE POPULATION}

The psychosocial data for this study were obtained between the second and third series of community wide data collections. The sample consisted of 529 men and 615 women, $40 \%$ of the cohort of men and women, ages 35-69, who were examined during Series II (1962-1965), and who were still living in the community when their dwelling units came into the sample for this study in 1966-67. About $60 \%$ of the men and women were evenly distributed among the 5-yr age groups between 35 and $49 \mathrm{yr}$. After that, as expected, the proportions in the 5-yr age groups steadily decreased to a low of about 7\% in the group 65-69 yr. A structured interview, lasting from 1 to $2 \mathrm{hr}$, was conducted in the home with each respondent to obtain a complete lifetime history of residence, occupation and family composition. The physiologic and medical diagnostic data and the risk factor information concerning cigarette smoking habits were obtained during the Series II collection. Information concerning alcohol drinking habits was obtained during the Series I collection.

\section{EARLY LIFE SOCIAL INCONGRUITIES}

\section{Geographic mobility}

Gcographic residential mobility during childhood $(0-16 \mathrm{yr})$ was charactcrized by each of the seven variables described below and by a summary index described later. For some of the analyses, the variables were used with a wide range of 
categories; for others they were dichotomized. The dichotomy is described in parentheses. The first two variables indicate frequency of geographic mobility:

(1) Number of dwelling units lived in. (1-3; 4 or more)

(2) Number of places lived in. Places are locations or place names reported. (1-2; 3 or more)

The next five variables are derived from a coding scheme which categorized each place into one of 6 size-classes: under 2500 population; 2500-10,000; $10,000-50,000 ; 50,000-100,000 ; 100,000-500,000$; and 500,000 or more. Then number of years spent in each size-class was recorded. Mobility variables 3 and 4 reflect different aspects of the variety of community size experienced.

(3) Number of size-classes of places lived in. This measures the number of sizes of communities experienced. There is no indication here of the actual size of these communities. $(1 ; 2-6)$

(4) Similarity of sizes of places lived in. For this variable the 6 size-classes were collapsed into three (less than $10,000,10,000-100,000,100,000$ or more) and the respondent was classified as having lived during this period in places of similar size, moderately dissimilar size, or very dissimilar size. (Similar size; moderately and very dissimilar sizes)

Variables 3 and 4 are obviously related but not redundant since Variable 3 gives no indication of the similarity of the sizes experienced beyond one size. Variable 4 is meant to reflect those differences in ecological characteristics that may be associated with size of places and which are likely to require adaptation to changes in those characteristics.

Mobility variables 5-7 are less measures of mobility than the preceding ones and more measures of time exposed to characteristics associated with places of various sizes.

(5) Number of years lived in small size places. Under 10,000 population. (0-15; 16-17)

(6) Number of years lived in medium size places. 10,000-100,000 population (0; 1 or more)

(7) Number of years lived in large size places. 100,000 or more. ( $0 ; 1$ or more)

Distributions for the mobility variables (data not shown) indicated that, in general, there were no sex-age differences, and that over half the study group did very little moving around during childhood. Fifty per cent lived in three or fewer dwelling units; over $60 \%$ lived in one or two places, and about $60 \%$ lived in places of one size class. By definition, places of one size class were of similar size and that turned out to be the small size class, under 10,000 population. Because variables 6 and 7 are largely complementary of 5 and add nothing to this analysis, they are not discussed further.

(8) Mobility index. In order to combine the effects of the various kinds of mobility measured by the 3 separate variables-number of dwelling units, number of places and similarity of size of places - the 3 variables were dichotomized, arranged hierarchically and an a priori rank value was assigned to the resulting categories. 
These rank values were based on the relative social impact of the 3 variables as hypothesized. The index has 5 categories which are ranked in order from stable to mobile, composed in the following manner:

(1) Lived in similar sized places only; few places (1 or 2); few (1-3) dwelling units. (Stable).

(2) Lived in similar sized places only; few places; many dwelling units (4 or more).

(3) Lived in similar sized places only; many places (3 or more); few or many dwelling units.

(4) Lived in dissimilar sized places; few places; few or many dwelling units.

(5) Lived in dissimilar sized places; many places; few or many dwelling units. (Highly mobile).

Other possible categories combining these three variables had too few people in them and were collapsed appropriately into the last three categories. It was hypothesized that, at the very least, categories 1 and 5 of this ranking should yield two extremely different groups even if the rank order values within the hierarchy were not borne out in the relationships examined. In the development of this index, consideration was given to including the variable, number of years lived in small size places. However, preliminary analysis of the data, when this variable was included with the other three, showed that it did not contribute to understanding any of the relationships under study.

\section{Parental deprivation}

Parental deprivation was described by the number of years lived without one or both natural parents during childhood. About $75 \%$ of the study sample lived with both parents all during this period and the remaining $25 \%$ were evenly distributed across the range of $1-16 \mathrm{yr}$ of deprivation. Preliminary analysis indicated that, among those who had some years of deprivation, there were no differences related to the number of years. As a result, all final analyses were performed with this variable dichotomized into 'no deprivation' and 'some', the latter meaning $1-16 \mathrm{yr}$ without one or both natural parents.

\section{Parental status incongruency}

Risk factors and disease conditions were studied in relation to parental status congruency or incongruency in the three aspects listed below and as a composite index. The separate measures concerned a match or discrepancy between the respondent's:

(1) Father's education and father's occupation;

(2) Mother's education and father's occupation; and

(3) Father's education and mother's education.

Categories of parents' education and occupation were classified as congruent or incongruent depending upon the relationship found between these variables in this population. The congruent category for measures 1 and 2 was composcd of white collar workers with 12 or more years of education, father's or mother's education as appropriate; and blue collar workers and farmers with less than 
$12 \mathrm{yr}$ of education, father's or mother's education as appropriate. The incongruent category was composed of the complementary pairing of these characteristics. For measure 3, the congruent category was defined as those whose parents' education levels matched exactly when those levels were classed in one of the five categories: $<8 \mathrm{yr}, 8 \mathrm{yr}, 9-11 \mathrm{yr}, 12 \mathrm{yr}$, and some or completed college. The incongruent category was composed of those whose parents did not have this match.

(4) Status Incongruency Index. This was constructed by adding the code values 1 or 2 for each of the three measures, yielding scores ranging from 3 for most congruent to 6 for least. Unlike the geographic mobility index, this one was not based on a hierarchical arrangement because there was no a priori hypothesis concerning relative importance of the component measures.

\section{HEALTH RISK FACTORS}

The health risk factors under study were:

(1) Systolic blood pressure.

(2) Diastolic blood pressure, fifth phase. Blood pressure of respondents in a sitting position was taken by an examining physician using a standard manometer.

(3) Blood glucose level. A blood glucose score was used which is age adjusted and specific for sex and the test conditions, amount of time and quantity of food eaten before blood was drawn and whether or not the $100 \mathrm{~g}$ challenge of $\mathrm{CHO}$ was taken. Blood glucose values were determined by autoanalyzer using the modified Hoffman method [20].

(4) Serum cholesterol. These values were determined by the Abell-Kendal method.

(5) Serum uric acid. A serum uric acid score was used which is age and sex adjusted based on determinations by the autoanalyzer using the automatic colorimetric method [21].

(6) Lung function as measured by forced expiratory volume in one secondF.E.V.1.0. A score was used which was sex, age and height adjusted. For this variable only, the higher the value the lower the risk for the associated poor health conditions [22].

(7) Adiposity. This was indicated by a sex-specific index value calculated by a linear function of weight over height squared and the sum of the right triceps and right subscapular skinfolds.

(8) Current smoking habit. Two measures were used to indicate this. The first is a categorical variable describing whether the respondent was a current smoker, an ex-smoker or one who had never smoked. The second was a continuous variable consisting of number of cigarettes smoked currently per day including the value of zero for ex- and never-smokers.

(9) Current alcohol drinking habits. Two measures were used which were parallel to the smoking variables. The amount of alcohol currently consumed was measured in units, one of which is roughly equivalent to $5 \mathrm{~g}$ of alcohol per week.

Mean and standard deviations for all the continuous risk factors are given in Table 1. 
Table 1. Means and Standard deviations of Risk factors of Respondents, ages 35-69, in the SOCIAL LIFE HISTORY SAMPLE, BY SEX AND AGE

\begin{tabular}{|c|c|c|c|c|c|c|}
\hline Risk factors & $35-49$ & $\begin{array}{l}\text { Males } \\
5069\end{array}$ & Total & $35-49$ & $\begin{array}{c}\text { Females } \\
50-69\end{array}$ & Total \\
\hline \multicolumn{7}{|l|}{$\begin{array}{l}\text { Blood pressure, } \\
\text { systolic }\end{array}$} \\
\hline Mean & $134.7^{*}$ & $142.4^{*}$ & 138.1 & $129.1^{*}$ & $145.2^{*}$ & 135.8 \\
\hline S.D. & 16.92 & 20.00 & 18.70 & 16.44 & 24.25 & 21.54 \\
\hline \multicolumn{7}{|l|}{$\begin{array}{l}\text { Blood pressure. } \\
\text { diastolic } 5 \text { th phase }\end{array}$} \\
\hline Mean & $83.3^{*}$ & $86.1^{*}$ & 84.5 & $80.2^{*}$ & $86.0^{*}$ & 82.6 \\
\hline S.D. & 11.77 & 11.70 & 11.81 & 11.07 & 14.50 & 12.94 \\
\hline \multicolumn{7}{|l|}{$\begin{array}{l}\text { Blood glucose } \\
\text { score }^{(a)}\end{array}$} \\
\hline Mean & 10.00 & 10.12 & 10.05 & 10.03 & 10.09 & 10.06 \\
\hline S.D. & 1.021 & 1.123 & 1.066 & 0.973 & 0.973 & 0.973 \\
\hline \multicolumn{7}{|l|}{ Serum cholesterol } \\
\hline Mean & $229.0^{*}$ & $234.9^{*}$ & 231.6 & $213.1^{*}$ & $246.5^{*}$ & 226.9 \\
\hline S.D. & 39.05 & 40.14 & 39.59 & 34.81 & 49.78 & 44.73 \\
\hline \multicolumn{7}{|l|}{$\begin{array}{l}\text { Serum uric acid } \\
\text { score }^{\text {b) }}\end{array}$} \\
\hline Mean & 4.55 & 4.53 & 4.54 & 4.48 & 4.64 & 4.54 \\
\hline S.D. & 1.017 & 0.997 & 1.007 & 0.924 & 1.010 & 0.960 \\
\hline \multicolumn{7}{|l|}{ F.E.V. ${ }_{1.0}$ score $^{(\mathrm{a})}$} \\
\hline Mean & $9.78^{*}$ & $9.60^{*}$ & 9.71 & $10.00^{*}$ & $9.80^{*}$ & 9.92 \\
\hline S.D. & 1.010 & 1.092 & 1.049 & 0.914 & 0.835 & 0.887 \\
\hline \multicolumn{7}{|l|}{ Adiposity index } \\
\hline Mean & $117.4^{*}$ & $119.9^{*}$ & 118.5 & $122.0^{*}$ & $131.2^{*}$ & 125.8 \\
\hline S.D. & 126.1 & 153.1 & 138.8 & 222.2 & 239.3 & 233.8 \\
\hline \multicolumn{7}{|l|}{$\begin{array}{l}\text { No. cigarettes } \\
\text { currently }\end{array}$} \\
\hline Mean & $16.5^{*}$ & $12.0^{*}$ & 14.6 & $6.6^{*}$ & $4.5^{*}$ & 5.7 \\
\hline S.D. & 17.13 & 15.34 & 16.53 & 10.74 & 9.04 & 10.12 \\
\hline \multicolumn{7}{|l|}{$\begin{array}{l}\text { No. units alcohol } \\
\text { currently }\end{array}$} \\
\hline Mean & $13.5^{*}$ & $18.3^{*}$ & 15.6 & $5.0^{*}$ & $4.3^{*}$ & 4.7 \\
\hline S.D. & 21.87 & 39.07 & 30.67 & 11.57 & 10.43 & 11.10 \\
\hline Number of respondents & 302 & 227 & 529 & 360 & 255 & 615 \\
\hline
\end{tabular}

(a) These scores are adjusted for age and sex as well as for other variables related to the specific measurements.

(b) These scores, which were adjusted for sex and age, were determined for a sub-set of the study group because of a change in method of serum uric acid analysis. The numbers for the sex/age groups are: $170,118,288,204,127,331$.

(c) One unit equals about $5 \mathrm{~g}$ of alcohol; one bottle of beer, for example, is coded as 3 units. Since alcohol consumption data were collected during Series I exams and not during Series II, the number of respondents is smaller than for the other variables. The numbers for the sex/age groups are: $244,190,434,297,215,512$.

*The differences among the means for the four age-sex groups are significant $P<0.001$.

\section{DIAGNOSED AND DEFINED CHRONIC CONDITIONS AND MORTALITY}

The diagnosed or defined chronic conditions were:

(1) Coronary heart disease. Suspect and probable levels were diagnosed according to definitions using (a) Minnesota criteria categorization of electrocardiographic findings, and (b) history.

(2) Hypertension. Suspect and probable levels were coded, probable classification being assigned to those who had a blood pressure reading of 200 or over systolic, 
or 110 or over diastolic fifth phase. Those not classified as probable were assigned suspect classification if the blood pressure reading was 160-199 systolic or 95-109 diastolic.

(3) Diabetes. Suspect and probable levels were diagnostically determined by staff physicians on the basis of history and examination findings. The two levels were combined for most analyses because of the small number of cases.

(4) Chronic bronchitis. Suspect and probable levels were determined on the basis of responses to questions regarding frequency, duration and pattern of cough or phlegm [22].

(5) Asthma. Suspect and probable levels were determined by staff physicians on the basis of history and examination using defined criteria [23].

(6) A variable was also constructed called Number of Chronic Conditions which indicated the degree of aggregation of the five diseases within individuals. For this variable the condition was treated as present if it was diagnosed at either the suspect or probable level.

(7) Mortality status was ascertained as of the summer of 1972. This variable, therefore, contains the information about incidence of death between the time of interview in 1966 or 1967 and summer of 1972 . Mortality status data were ascertained for all members of the Tecumseh cohort by direct interview of family or friends and death certificate information was obtained for all deaths.

Table 2 presents the prevalence of the diseases, percentages with various degrees of disease prevalence and per cent who died in the 6-yr period. It should be noted that cumulative prevalence is given for coronary heart disease (CHD), diabetes and asthma. Cumulative prevalence refers to conditions present at the time of the examination or at any other time in the past. Prevalence within the last year is given for chronic bronchitis. Hypertension is derived from blood pressure readings at the examination.

\section{ANALYTIC METHODS}

Inasmuch as many health risk factor levels, prevalence of most of the chronic conditions studied and mortality rates are known to be related to sex and age, all analyses took these two variables into account when testing for the separate effects of the early life stress variables. Relationships between the separate geographic mobility measures and the continuous risk factors were studied by multiple regression techniques. One way analysis of variance was used to study the relationships between the other life stress variables and the continuous health risk factors. Contingency table analysis was used for the rest of the analyses.

The hypotheses tested were that higher frequencies of illness and significantly higher levels of risk factors would be found among respondents who, during the period of early family life, ages $0-16$ :

(1) Had higher levels of geographic mobility as evidenced by: (a) moving more frequently from dwelling unit to dwelling unit: (b) moving more frequently from place (locality) to place; (c) moving about among places of different size classes; (d) having lived in places of very dissimilar size; (e) having spent some or all of the childhood years in communities of size larger than 10,000; (f) having combinations of high mobility values for these measures. 
LIFE HISTORY SAMPLE, BY AGE AND SEX

\begin{tabular}{|c|c|c|c|c|c|c|c|c|}
\hline Selected conditions & $35-49$ & $50-69$ & les & $\begin{array}{l}\text { No. of } \\
\text { Cases }\end{array}$ & $35-49$ & $\begin{array}{r}\mathrm{Fem} \\
\mathrm{A}\end{array}$ & 35 & $\begin{array}{l}69 \\
\text { No. of } \\
\text { Cases }\end{array}$ \\
\hline \multicolumn{9}{|l|}{ Coronary heart disease } \\
\hline $\begin{array}{l}\text { Suspect or probable } \\
\text { Hypertension }\end{array}$ & $2.3 \%$ & $11.5^{\circ} \%$ & $6.3^{\circ}$ & 33 & $3.9^{\circ}$ & $10.2 \%$ & $6.7_{0}^{\circ}$ & 41 \\
\hline Probable & 10.9 & 10.1 & 10.6 & 56 & 9.2 & 12.9 & 10.7 & 66 \\
\hline Suspect & 14.2 & 21.1 & 17.2 & 91 & 6.4 & 25.1 & 14.1 & 87 \\
\hline \multicolumn{9}{|l|}{ Diabetes } \\
\hline Suspect or probable & 2.6 & 4.4 & 3.4 & 18 & 1.1 & 5.1 & 2.8 & 17 \\
\hline \multicolumn{9}{|l|}{ Chronic hronchitis } \\
\hline Probable & 14.9 & 17.2 & 15.9 & 84 & 4.4 & 5.1 & 4.7 & 29 \\
\hline Suspect & 24.8 & 27.8 & 26.1 & 138 & 19.4 & 21.2 & 20.2 & 124 \\
\hline \multicolumn{9}{|l|}{ Asthma } \\
\hline Probable & 5.0 & 6.2 & 5.5 & 29 & 7.2 & 8.2 & 7.6 & 47 \\
\hline Suspect & 5.6 & 6.6 & 6.0 & 32 & 7.2 & 6.3 & 6.8 & 42 \\
\hline \multicolumn{9}{|l|}{$\begin{array}{l}\text { Combination of above five } \\
\text { conditions at probable or } \\
\text { suspect levels }\end{array}$} \\
\hline No conditions & 41.4 & 30.8 & 36.9 & 195 & 54.7 & 31.0 & 44.9 & 276 \\
\hline One & 40.4 & 40.1 & 40.2 & 213 & 32.6 & 47.1 & 38.5 & 237 \\
\hline Two & 14.6 & 22.5 & 18.0 & 95 & 11.9 & 18.8 & 14.8 & 91 \\
\hline Three & 3.6 & 6.6 & 4.9 & 26 & 0.8 & 2.7 & 1.6 & 10 \\
\hline Four & 0.0 & 0.0 & 0.0 & 0 & 0.0 & 0.4 & 0.2 & 1 \\
\hline Five & 0.0 & 0.0 & 0.0 & 0 & 0.0 & 0.0 & 0.0 & 0 \\
\hline \multicolumn{9}{|l|}{ Mortality between } \\
\hline 1966 and 1972 & 1.0 & 10.1 & 4.9 & 26 & 0.8 & 4.3 & 2.3 & 14 \\
\hline Total No. of Respondents & 302 & 227 & & 29 & 360 & 255 & & \\
\hline
\end{tabular}

(2) Had parental deprivation as evidenced by living without one or both natural parents for one or more years during the period.

(3) Experienced parental status incongruencies as evidenced by: (a) living with parents whose formal education levels were incongruent in status level with the occupation of the father; (b) living with parents whose formal education levels were different; (c) having combination of these parental status incongruencies.

\section{RESULTS}

For women, geographic mobility, as defined here by the group of 5 separate mobility measures, was related significantly as predicted to the 9 continuous health risk factors considered as a group and to the 9 categorical health variables considered as a group. For the 9 continuous risk factors, regressions of each on age and mobility measure were performed. Among these relationships, the mobility variables contributed significantly at the 0.10 level to more than $25 \%$ of the 45 regression equations. Specifically, one or more of the 5 mobility measures had a significant relationship with diastolic blood pressure, serum cholesterol, F.E.V., adiposity, number of cigarettes smoked currently and amount of alcohol consumed currently (Table 3 ). The categorical health variables were related to mobility within sex and age group by contingency table analysis. Among these relationships, there 


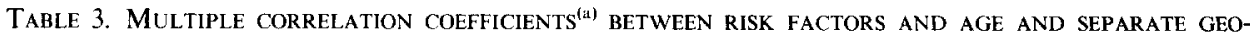
GRAPHIC MOBILITY MEASURES, BY SEX

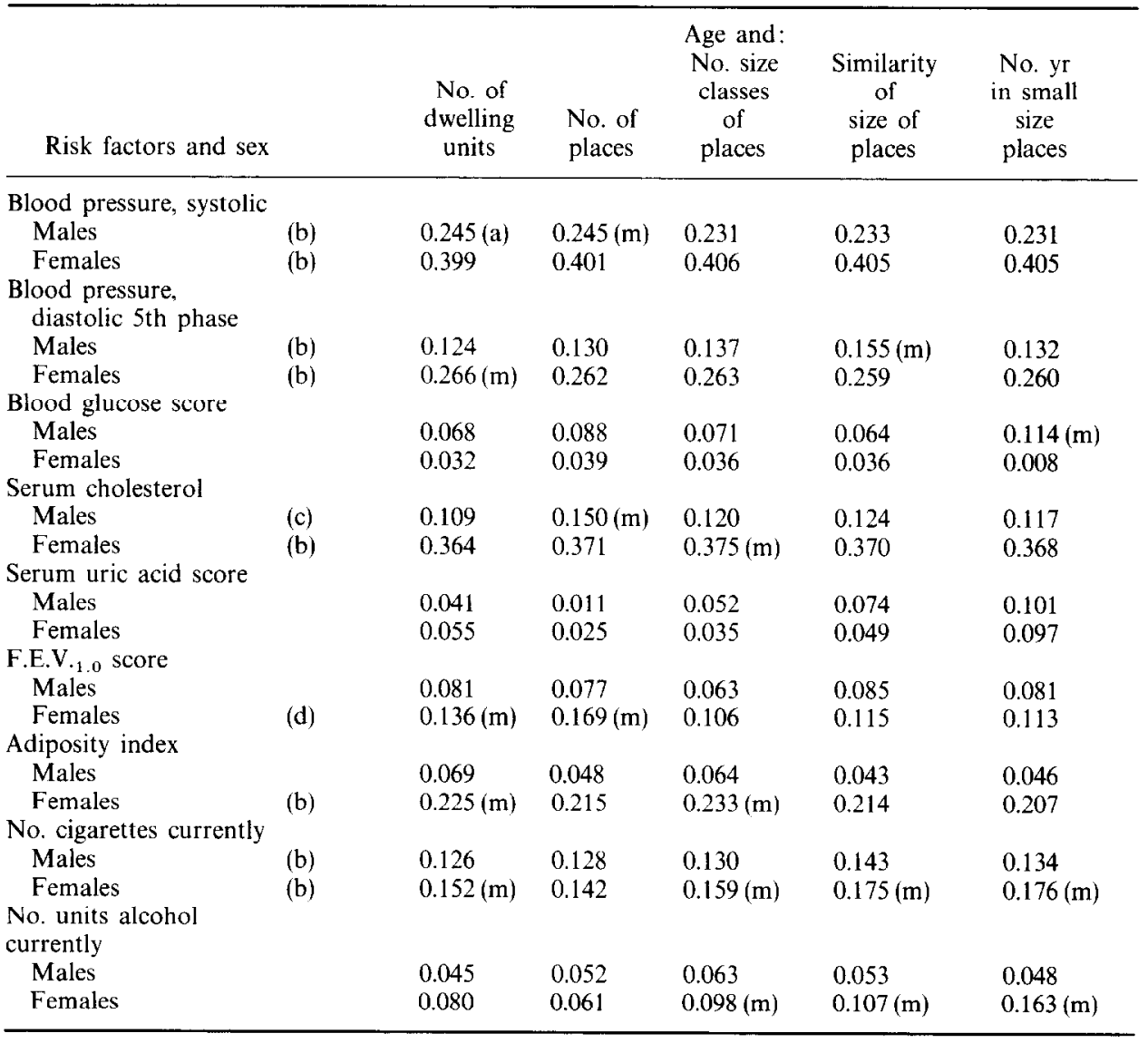

(a) $R$ 's are statistically significantly different from 0 when: $R=0.098-0.114$, then $P \leq 0.10$; $R=0.115-0.136$, then $P \leq 0.05 ; R=0.137+$, then $P \leq 0.01$.

(b) For all mobility variables, age contributed significantly to the regression equation with $P \leq 0.01$.

(c) Age contributed significantly to the variable, number of dwelling units, with $P \leq 0.05$, and to the other mobility variables with $P \leq 0.01$.

(d) For all mobility variables, age contributed significantly to the regression equation with $P \leq 0.05$. That is, the coefficient for age in the regression equation is significantly different from zero with $P \leq 0.05$.

(m) The mobility variable contributed to the regression equation with $P \leq 0.10$.

were 17 or $38 \%$ significant differences in the 45 possible for older women and 14 or $31 \%$ significant differences in the 45 possible for younger women. Specifically, one or more of the 5 measures had a significant relationship with $\mathrm{CHD}$, diabetes, chronic bronchitis, asthma, number of chronic conditions, having ever smoked and having ever drunk. See Tables $4 a$ and $4 b$ for the summary of the significance of these relationships. See Tables 5-9 for the details.

No one of the 5 component measures of geographic mobility was significantly associated with higher levels of all the 9 continuous risk factors or all 9 of the categorical variables. However, each of the five, considered individually, was related 
Table 4a. Significance of the Relationships BetWeen CaTegorized health CHARACTERISTICS AND MOBILITY MEASURES, BY SEX AND AGE

\begin{tabular}{|c|c|c|c|c|c|c|}
\hline \multirow{3}{*}{$\begin{array}{c}\text { Categorized } \\
\text { health characteristics } \\
\text { and sex }\end{array}$} & \multicolumn{6}{|c|}{ Mobility measures and age } \\
\hline & \multicolumn{2}{|c|}{$\begin{array}{c}\text { No. of } \\
\text { dwelling units }\end{array}$} & \multicolumn{2}{|c|}{$\begin{array}{l}\text { No. of } \\
\text { places }\end{array}$} & \multicolumn{2}{|c|}{$\begin{array}{l}\text { No. of } \\
\text { size classes }\end{array}$} \\
\hline & $35-49$ & $50-69$ & $35-49$ & $50)-69$ & $35-49$ & $50-69$ \\
\hline \multicolumn{7}{|l|}{ Deceased } \\
\hline Males & 0 & 0 & 0 & 0 & 0 & 0 \\
\hline Females & 0 & 0 & 0 & 0 & 0 & 0 \\
\hline \multicolumn{7}{|l|}{ CHD } \\
\hline Males & 0 & 0) & 0) & 0 & 0 & $\left(\begin{array}{l}+* * \\
+\end{array}\right)$ \\
\hline Females & 0 & $\dagger^{*}$ & 0 & $+* *$ & 0 & $+* *$ \\
\hline \multicolumn{7}{|l|}{ Hypertension } \\
\hline Males & 0 & $+*$ & 0 & $+*$ & 0 & 0 \\
\hline Females & 0 & 0 & 0 & 0 & 0 & 0 \\
\hline \multicolumn{7}{|l|}{ Diabetes } \\
\hline Males & 0 & 0 & 0 & 0 & 0 & 0 \\
\hline Females & $\dagger^{*}$ & 0 & $t^{*}$ & 0 & 0 & $\dagger^{*}$ \\
\hline \multicolumn{7}{|l|}{ Chronic bronchitis } \\
\hline Males & 0 & 0 & 0 & 0 & 0 & 0 \\
\hline Females & 0 & $(\stackrel{+*}{+})$ & 0 & 0 & $\dagger^{* * *}$ & $+* *$ \\
\hline \multicolumn{7}{|l|}{ Asthma } \\
\hline Males & 0 & 0 & 0 & $\left({ }_{ \pm}^{* * *}\right)$ & 0 & $\left(\begin{array}{l}+* * \\
+\end{array}\right)$ \\
\hline Females & 0 & $\dagger * *$ & 0 & 0 & 0 & 0 \\
\hline \multicolumn{7}{|l|}{ Cigarette smokers } \\
\hline Males & 0 & 0 & 0 & 0 & 0 & 0 \\
\hline Females & $\dagger * *$ & 0 & $\dagger^{* *}$ & 0 & $\dagger * *$ & 0 \\
\hline \multicolumn{7}{|l|}{ Alcohol drinkers } \\
\hline Males & 0 & 0 & 0 & 0 & 0 & 0 \\
\hline Females & $\dagger * *$ & 0 & $\dagger^{* *}$ & 0 & $\dagger * *$ & $\dagger^{* *}$ \\
\hline \multicolumn{7}{|l|}{ No. of chronic conditions } \\
\hline Males & 0 & 0 & 0 & 0 & 0 & 0 \\
\hline Females & 0 & 0 & 0 & 0 & 0 & *: \\
\hline
\end{tabular}

fIndicates a significant relationship in the hypothesized direction; i.e., more of the mobile have the poor health characteristic.

Indicates a large difference in the opposite direction.

${ }^{*} P \leq 0.10,{ }^{* *} P \leq 0.05,{ }^{* * *} P \leq 0.012 \times 2$ tables. Fisher's Exact Test was used. (a) No monotonic directionality was found for the 3-category variable, number of chronic conditions. However, the chi-square goodness-of-fit test showed the distribution for the mobile significantly different from that to be expected considering the prevalence of the five diseases.

to the health variables, as a group, frequently enough to be considered of some importance. The strongest mobility measures proved to be number of size-classes of places lived in, with 4 significant relationships out of 9 possible with the continuous risk factors and 8 out of 18 possible with the categorical variables $(9$ possible each for young and older women). The next most important component measure was number of years lived in small size places with 2 out of 9 significant with the continuous risk factors and 7 out of 18 significant with the categorical variables. The least important component measure was number of places lived in, with 1 out of 9 significant with the continuous risk factors and 4 out of 18 with the categorical health conditions.

Among women, the continuous risk factor most frequently related to the 5 mobility measures is number of cigarettes smoked, with significant relationships to 4 
TABLE 4b. SigNIFICANCE OF THE RELATIONSHIPS BETWEen CATEGORIZED HEALTH CHARACTERISTICS AND MOBILITY MEASURES, BY SEX AND AGE

\begin{tabular}{|c|c|c|c|c|}
\hline \multirow{3}{*}{$\begin{array}{c}\text { Categorized } \\
\text { health characteristics } \\
\text { and sex }\end{array}$} & \multicolumn{4}{|c|}{ Mobility measures and age } \\
\hline & \multicolumn{2}{|c|}{$\begin{array}{c}\text { Similarity of size } \\
\text { of places }\end{array}$} & \multicolumn{2}{|c|}{$\begin{array}{l}\text { Number of years in } \\
\text { small places }\end{array}$} \\
\hline & $35-49$ & $50-69$ & $35-49$ & $50-69$ \\
\hline \multicolumn{5}{|l|}{ Deceased } \\
\hline Males & 0 & 0 & 0 & 0 \\
\hline Females & 0 & 0 & 0 & 0 \\
\hline \multicolumn{5}{|l|}{ CHD } \\
\hline Males & 0 & 0 & 0 & $\left(\ddagger^{* *}\right)$ \\
\hline Females & 0 & $\dagger^{* *}$ & 0 & $\dagger * *$ \\
\hline \multicolumn{5}{|l|}{ Hypertension } \\
\hline Males & 0 & 0 & 0 & 0 \\
\hline Females & 0 & 0 & 0 & 0 \\
\hline \multicolumn{5}{|l|}{ Diabetes } \\
\hline Males & 0 & 0 & 0 & 0 \\
\hline Females & 0 & $\dagger^{*}$ & 0 & $\dagger * *$ \\
\hline \multicolumn{5}{|l|}{ Chronic bronchitis } \\
\hline Males & 0 & 0 & 0 & $\dagger * *$ \\
\hline Females & $\dagger^{* *}$ & 0 & $\dagger * *$ & 0 \\
\hline \multicolumn{5}{|l|}{ Asthma } \\
\hline Males & 0 & $\left(\ddagger^{* *}\right)$ & 0 & 0 \\
\hline Females & 0 & 0 & 0 & 0 \\
\hline \multicolumn{5}{|l|}{ Cigarette smokers } \\
\hline Males & 0 & 0 & 0 & $\dagger * *$ \\
\hline Females & $\dagger^{*}$ & $\dagger * *$ & $\dagger^{* * *}$ & $\dagger * *$ \\
\hline \multicolumn{5}{|l|}{ Alcohol drinkers } \\
\hline Males & 0 & 0 & 0 & $\dagger * *$ \\
\hline Females & 0 & $\dagger^{* * *}$ & $\dagger * *$ & $\dagger * *$ \\
\hline \multicolumn{5}{|l|}{ No. of chronic conditions } \\
\hline Males & 0 & 0 & 0 & 0 \\
\hline Females & 0 & *a & 0 & 0 \\
\hline
\end{tabular}

†Indicates a significant relationship in the hypothesized direction; i.e., more of the mobile have the poor health characteristic.

$\ddagger$ Indicates a large difference in the opposite direction.

${ }^{*} P \leq 0.10,{ }^{* *} P \leq 0.05,{ }^{* * *} P \leq 0.012 \times 2$ tables. Fisher's Exact Test was used.

(a) No monotonic directionality was found for the three-category variable, number of chronic conditions. However, the chi-square goodness-of-fit test showed the distribution for the mobile significantly different from that to be expected considering the prevalence of the five diseases.

of the 5 measures. Mean number of alcohol units consumed was significantly related to 3 of the 5 measures; adiposity and F.E.V. were related to 2 measures each. The categorical health variables most frequently related to the 5 measures of mobility were cigarette smoking habits and alcohol drinking habits, each significantly related 7 out of a possible 10 times. (There are 5 possible relationships each for the younger and the older women.) Among the younger women, cigarette smoking was related to all 5 measures and alcohol drinking to 4 of the 5 measures. CHD was significantly related to all 5 measures among the older women; diabetes was significant twice among younger women and three times among older women.

Still looking at the relationships among women, the mobility index was not related in the hypothesized monotonic manner to either set of dependent health variables, continuous risk factors or categorical conditions or characteristics. It also did not consistently separate the extreme high and low values of the health 
TABLE 5. COMPARISON OF RESPONDENTS WHO LIVED IN FEW WITH THOSE WHO LIVED IN MANY DWELLING

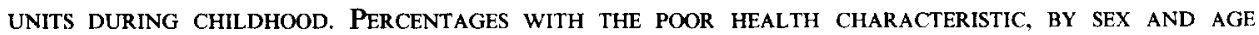

\begin{tabular}{|c|c|c|c|c|c|c|c|c|}
\hline \multirow[b]{3}{*}{ Health characteristics } & \multicolumn{4}{|c|}{ Males } & \multicolumn{4}{|c|}{ Females } \\
\hline & \multicolumn{4}{|c|}{$\begin{array}{lc}35-49 \text { years } & 50-69 \text { years } \\
\text { Number of dwelling units }(\%)\end{array}$} & \multicolumn{4}{|c|}{$\begin{array}{l}35-49 \text { years } 50-69 \text { years } \\
\text { Number of dwelling units }\left({ }_{0}^{\circ}\right)\end{array}$} \\
\hline & Few & Many & Few & Many & Few & Many & Few & Many \\
\hline Deceased & 1.3 & 0.7 & 10.4 & 9.3 & 0.6 & 1.1 & 2.2 & 5.5 \\
\hline CHD & 1.3 & 3.6 & 11.3 & 12.8 & 4.1 & 4.0 & $7.4 *$ & 13.6 \\
\hline Hypertension & 27.5 & 21.7 & 27.6 & $* 37.2$ & 15.7 & 16.4 & 35.3 & 41.8 \\
\hline Diabetes & 2.6 & 2.2 & 3.7 & 4.7 & $0.0 *$ & 2.3 & 4.4 & 6.4 \\
\hline Chronic bronchitis & 38.6 & 42.8 & 45.5 & 46.5 & 20.4 & 26.0 & $30.9\left(^{*}\right)$ & 22.7 \\
\hline Asthma & 10.5 & 11.6 & 14.2 & 10.5 & 13.4 & 15.8 & $8.8 * *$ & 20.9 \\
\hline $\begin{array}{l}\text { Cigarette smokers } \\
\text { current or past }\end{array}$ & 79.7 & 82.5 & 65.4 & 70.2 & $39.5 * *$ & 53.1 & 33.1 & 29.4 \\
\hline $\begin{array}{l}\text { Alcohol drinkers } \\
\text { current or past (a) }\end{array}$ & 91.4 & 88.8 & 90.7 & 87.8 & $69.0 * *$ & 80.0 & 65.3 & 66.0 \\
\hline No. of chronic conditions & & & & & & & & \\
\hline One & 37.9 & 42.8 & 41.8 & 37.2 & 32.6 & 32.2 & 47.1 & 46.4 \\
\hline Two or more & 19.6 & 17.4 & 26.9 & 33.7 & 9.9 & 15.8 & 19.1 & 26.4 \\
\hline Number of respondents & 153 & 138 & 134 & 86 & 172 & 177 & 136 & 110 \\
\hline
\end{tabular}

${ }^{*} P \leq 0.10 ;(*)$ difference is in direction opposite to prediction.

${ }^{* *} P \leq 0.05$.

(a) Data available only for a subset of the study group. Numbers for Alcohol Drinkers are: 128. 116 , 118, 74, 142, 150, 121, 97.

Table 6. Comparison of Respondents Who lived in FEW Places With ThOSE Who lived IN MANY places during Childhood. Percentages With the poOr health Characteristic, by SEX and age

\begin{tabular}{|c|c|c|c|c|c|c|c|c|}
\hline \multirow[b]{4}{*}{ Health characteristics } & \multicolumn{4}{|c|}{ Males } & \multicolumn{4}{|c|}{ Females } \\
\hline & \multirow{2}{*}{\multicolumn{2}{|c|}{$\begin{array}{l}35-49 \text { years } \\
\text { Number of pl }\end{array}$}} & \multirow{2}{*}{\multicolumn{2}{|c|}{$\begin{array}{l}50-69 \text { years } \\
s \text { lived in }(\%)\end{array}$}} & \multicolumn{3}{|c|}{$35-49$ years $\quad 50-69$} & \multirow{2}{*}{$\begin{array}{l}\text { years } \\
\text { in }(\%)\end{array}$} \\
\hline & & & & & Number & of pla & es lived $\mathrm{i}$ & \\
\hline & Few & Many & Few & Many & Few & Many & Few & Many \\
\hline Deceased & 1.0 & 1.1 & 12.0 & 6.0 & 1.2 & 0.0 & 4.8 & 3.6 \\
\hline CHD & 1.9 & 3.4 & 12.0 & 10.5 & 3.7 & 4.3 & $7.2 * *$ & 17.9 \\
\hline Hypertension & 26.7 & 22.5 & $28.3 *$ & 38.8 & 15.4 & 16.2 & 35.7 & 41.7 \\
\hline Diabetes & 1.9 & 4.5 & 5.0 & 3.0 & $0.4 *$ & 2.6 & 4.8 & 6.0 \\
\hline Chronic bronchitis & 41.9 & 36.0 & 47.8 & 38.8 & 22.4 & 26.5 & 26.8 & 26.2 \\
\hline Asthma & $\$ 1.4$ & 9.0 & $\left.15.11^{* *}\right)$ & 6.0 & 16.2 & 11.1 & 12.5 & 17.9 \\
\hline Cigarette smokers & & & & & & & & \\
\hline current or past & 81.4 & 79.6 & 66.5 & 67.7 & $41.9 * *$ & 56.4 & 31.5 & 31.3 \\
\hline Alcohol drinkers & & & & & & & & \\
\hline current or past (a) & 91.4 & 88.2 & 91.3 & 85.0 & $69.4 * *$ & 84.9 & 63.1 & 70.7 \\
\hline No. of chronic conditions & & & & & & & & \\
\hline One & 40.5 & 41.6 & 39.0 & 41.8 & 32.8 & 31.6 & 44.1 & 51.2 \\
\hline Two or more & 19.5 & 15.7 & 30.8 & 25.4 & 12.0 & 14.5 & 20.2 & 26.2 \\
\hline Number of respondents & 210 & 89 & 159 & 67 & 241 & 117 & 168 & 84 \\
\hline
\end{tabular}

${ }^{*} P \leq 0.10$.

${ }_{* *} P \leq 0.05 ;(* *)$ difference is in direction opposite to prediction.

(a) Data available only for a subset of the study group. Numbers for Alcohol Drinkers are: 174, 76 , $138,60,199,99,149,75$. 
TABLE 7. COMPARISON OF RESPONDENTS WHO LIVED IN PLACES OF ONE SIZE-CLASS ONLY WITH THOSE

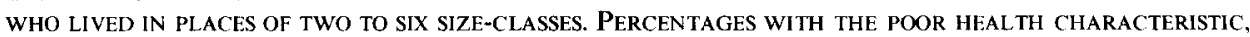
BY SEX AND AGE

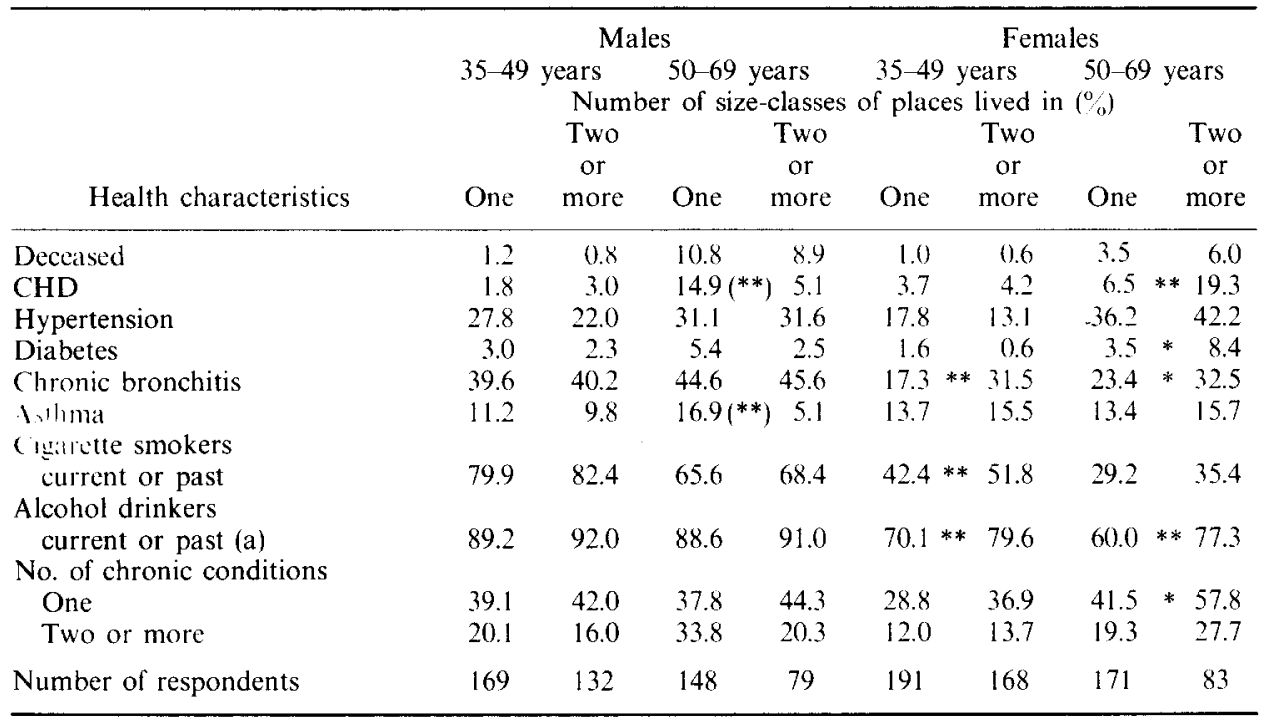

${ }^{*} P \leq 0.10$.

${ }^{* *} P \leq 0.05 ;\left({ }^{* *}\right)$ difference is in direction opposite to prediction.

(a) Data available only for a subset of the study group. Numbers for Alcohol Drinkers are: 139, 113, $132,67,157,142,150,75$.

TABLE 8. COMPARISON OF RESPONDENTS WHO LIVED IN PLACES OF SIMILAR SIZE WITH THOSE WHO LIVED in places of dissimilar size during ChildhoOd. Percentage with the poor health Characteristic, BY SEX ANID AGE

\begin{tabular}{|c|c|c|c|c|c|c|c|c|c|c|}
\hline \multirow[b]{4}{*}{$\begin{array}{c}\text { Health } \\
\text { characteristics }\end{array}$} & \multicolumn{4}{|c|}{ Males } & \multicolumn{6}{|c|}{ Females } \\
\hline & \multirow{2}{*}{\multicolumn{2}{|c|}{$35-49$ years }} & \multirow{2}{*}{\multicolumn{2}{|c|}{$\begin{array}{c}50-69 \text { years } \\
\text { Similarity of size o }\end{array}$}} & \multirow{2}{*}{\multicolumn{3}{|c|}{$\begin{array}{c}35-49 \text { years } \\
\text { places lived in }(\%)\end{array}$}} & \multicolumn{3}{|c|}{ 50-69 years } \\
\hline & & & & & & & & & & \\
\hline & Similar & $\begin{array}{l}\text { Dis- } \\
\text { similar }\end{array}$ & Similar & $\begin{array}{l}\text { Dis- } \\
\text { similar }\end{array}$ & Similar & & $\begin{array}{l}\text { Dis- } \\
\text { similar }\end{array}$ & Similar & & $\begin{array}{l}\text { Dis- } \\
\text { similar }\end{array}$ \\
\hline Deceased & 0.8 & 1.8 & 10.1 & 10.0 & 0.7 & & 1.2 & 4.9 & & 2.0 \\
\hline CHD & 2.0 & 3.6 & 12.9 & 5.0 & 4.0 & & 3.5 & 8.3 & $* *$ & 20.4 \\
\hline Hypertension & 26.4 & 20.0 & 31.6 & 30.0 & 16.3 & & 12.9 & 36.4 & & 44.9 \\
\hline Diabetes & 2.8 & 1.8 & 5.3 & 0.0 & 1.5 & & 0.0 & 3.9 & $*$ & 10.2 \\
\hline Chronic bronchitis & 40.2 & 38.2 & 44.9 & 45.0 & 21.5 & ** & 31.8 & 25.2 & & 30.6 \\
\hline Asthma & 9.8 & 14.6 & $15.0\left(^{* *}\right)$ & 2.5 & 15.2 & & 11.8 & 15.1 & & 12.2 \\
\hline $\begin{array}{l}\text { Cigarette smokers } \\
\text { current or past }\end{array}$ & 81.2 & 80.0 & 64.5 & 76.3 & 44.4 & * & 54.1 & 28.7 & $* *$ & 43.8 \\
\hline $\begin{array}{l}\text { Alcohol drinkers } \\
\text { current or past (a) }\end{array}$ & 90.3 & 91.1 & 89.0 & 91.7 & 72.8 & & 80.9 & 61.7 & $* *$ & 83.7 \\
\hline $\begin{array}{l}\text { No. of chronic } \\
\text { conditions }\end{array}$ & & & & & & & & & & \\
\hline One & 41.1 & 38.2 & 37.4 & 52.5 & 30.5 & & 38.8 & 43.2 & & 63.3 \\
\hline Two or more & 18.3 & 18.2 & 32.1 & 15.0 & 13.5 & & 10.6 & 21.4 & & 24.5 \\
\hline $\begin{array}{l}\text { Number of } \\
\text { respondents }\end{array}$ & 246 & 55 & 187 & 40 & 275 & & 85 & 206 & & 49 \\
\hline
\end{tabular}

${ }^{*} P \leq 0.10 ;\left({ }^{*}\right)$ difference is in direction opposite to prediction.

${ }^{* *} P \leq 0.05 ;\left({ }^{* *}\right)$ difference is in direction opposite to prediction.

(a) Data available only for a subset of the study group. Numbers for Alcohol Drinkers are: 207, 45, $163,36,232,68,183,43$. 
TABLE 9. COMPARISON OF RESPONDENTS WHO LIVED ALL THEIR CHILDHOOD (16-17 yr) WITH THOSF. WHO

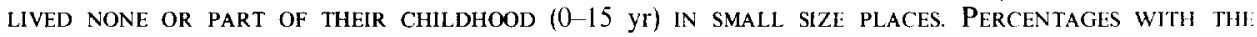
POOK HEALIH CHAKACILRISIIC, BY SEX ANI AGL

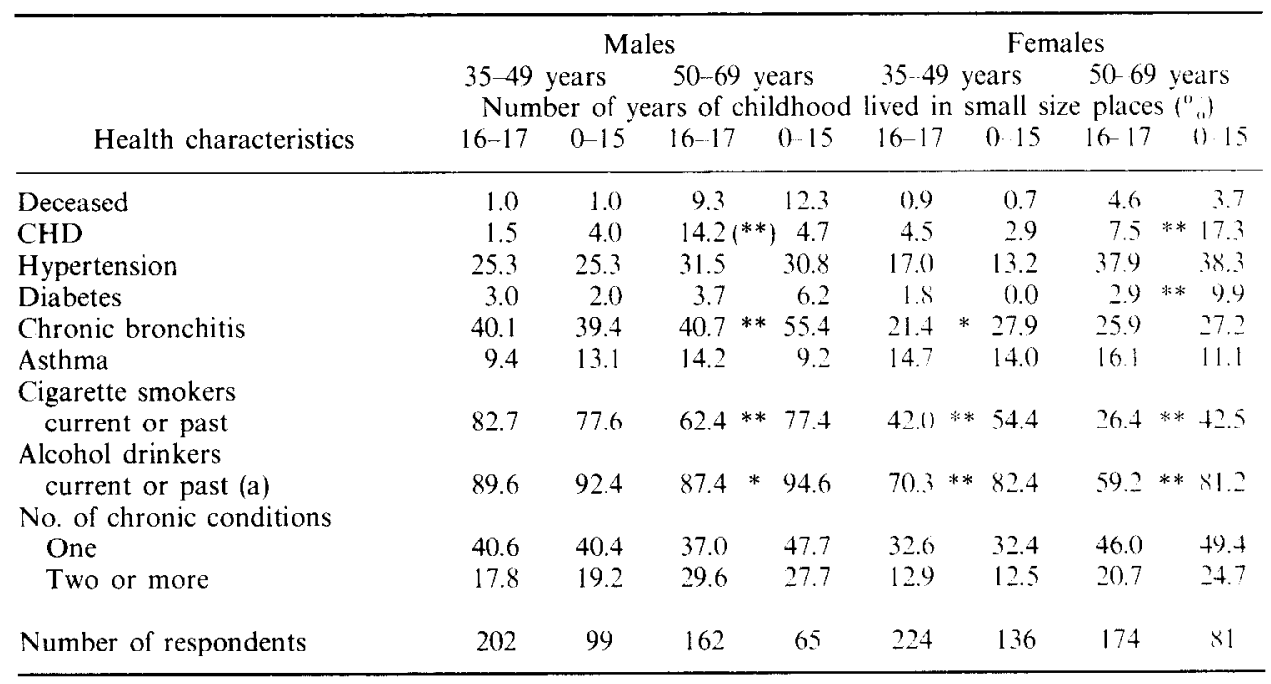

$* P \leq 0.10$

${ }^{* *} P \leq 0.05 ;\left({ }^{* *}\right)$ difference is in direction opposite to prediction.

(a) Data available only for a subset of the study group. Numbers for Alcohol Drinkers are: 173.79. 143. 56, 192. $108,157,69$.

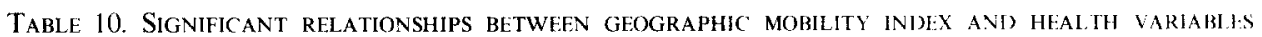
WITHIN SEX AGE GROLPS

\begin{tabular}{|c|c|c|c|c|c|c|}
\hline \multirow{2}{*}{$\begin{array}{c}\text { Sex, age and } \\
\text { health variables }\end{array}$} & \multirow{2}{*}{$\begin{array}{c}\text { Stable } \\
1\end{array}$} & \multicolumn{3}{|c|}{ Mobility index } & \multirow{2}{*}{$\begin{array}{c}\text { Mobile } \\
5\end{array}$} & \multirow{2}{*}{$\begin{array}{c}\text { Significance } \\
\text { level }\end{array}$} \\
\hline & & 2 & 3 & 4 & & \\
\hline \multicolumn{7}{|l|}{ Males $-50-69$ years } \\
\hline $\begin{array}{l}\text { Mean blood pressure } \\
\text { diastolic } 5 \text { th phase }\end{array}$ & 85.4 & 89.3 & 88.1 & 78.0 & 85.7 & $P=0.08^{1.11}$ \\
\hline $\begin{array}{l}\text { Mean no. of cigarettes } \\
\text { smoked currently }\end{array}$ & 10.5 & 19.2 & 7.8 & 14.8 & 16.4 & $P=0.01^{1+a 1}$ \\
\hline \multicolumn{7}{|l|}{ Females $-35-49$ years } \\
\hline $\begin{array}{l}\text { Mean no. of cigarettes } \\
\text { smoked currently }\end{array}$ & 5.0 & 5.6 & 7.8 & 5.0 & 10.3 & $P=0.02^{f .1 t}$ \\
\hline $\begin{array}{l}\text { Mean no. of units of } \\
\text { alcohol consumed currently }\end{array}$ & 3.9 & 2.4 & 5.5 & 11.0 & 7.3 & $P=0.03^{(i)}$ \\
\hline current or past smokers & 39.7 & 50.0 & 51.6 & 31.0 & 66.0 & $P=0.01^{(\mathrm{in})}$ \\
\hline$\%$ current or past drinkers & 68.5 & 75.0 & 8.3 .3 & 62.5 & 90.0 & $P=0.02^{(1) 1}$ \\
\hline \multicolumn{7}{|l|}{ Females--50-69 years } \\
\hline $\begin{array}{l}\text { Mean blood pressure } \\
\text { diastolic 5th phase }\end{array}$ & 83.4 & 89.0 & 86.6 & $x 6.8$ & 92.6 & $P=0.0 .3^{i .11}$ \\
\hline $\begin{array}{l}\text { Mean adiposity index } \\
\text { score }\end{array}$ & 1269.0 & 1322.0 & 1.345 .0 & 1421.0 & 1376.0 & $P=0.04^{\prime: 11}$ \\
\hline $\begin{array}{l}\text { Mean no. of cigarettes } \\
\text { smoked currently }\end{array}$ & 5.5 & 4.9 & 1.6 & 2.7 & 6.8 & $P=0.05^{f i t}$ \\
\hline$\%$ current or past smokers & 33.6 & 28.1 & 189 & 250 & 53.6 & $P=0.03^{|b|}$ \\
\hline
\end{tabular}

(a) Significance test was analysis of variance-- $F$ test.

(b) Significance test was chi-square. 
variables in association with the most mobile and stable index ranks for those relationships that were statistically significant. Only one of the 8 significant relationships showed this association, namely diastolic blood pressure for older women. For relationships with cigarette smoking, the most mobile group had the most smokers and concomitantly smoked the largest mean number of cigarettes, but the most stable group did not have the fewest smokers or smoke the least number of cigarettes. The other significant relationships showed various associations between health level and rank on the mobility index (see Table 10).

For men, geographic mobility, as represented by the set of separate measures or the index, was not related to the health variables, the set of continuous risk factors or the set of categorical conditions or characteristics.

In general, parental deprivation was not related to 18 health variables as predicted. In only one sex-age group. the older women, and for one set of health variables, the continuous risk factors, were there slightly more statistically significant relationships than expected by chance.

Parental status incongruence, as represented by the set of 3 separate measures and also the index combining these measures, was not found to be associated with the two sets of health variables among men or women. Some statistically significant relationships were found but with a very low frequency considering the total number of associations possible. Also these relationships were so scattered among the sex-age groups and the psychosocial and health variables as to indicate no pattern (Tables 11, 12).

\section{DISCUSSION AND CONCLUSIONS}

The significance and interpretation of these positive and negative results should be evaluated in the context of the study design which combined various features used relatively infrequently in similar studies. First, the sample is an area probability sample of an entire natural community, viz., a small midwestern city and its environs, populated mostly by northern European stock whose families had lived in the area for two or more generations. Except for the age restriction, there was no selection on the basis of health status, occupation, sex or other characteristics of the respondents, as is usual in other studies [24-27]. Second, the dependent health variables are several -5 chronic conditions, mortality status, and 9 physiologic and behavioral health risk factors associated with these conditions and others; the psychosocial variables belong to at least 3 categories as originally conceived. More frequently, studies relating psychosocial variables to some measure of health restrict that measure to one condition and perhaps its concomitant risk factors, or to mortality.

When this research was undertaken, the expectation was that hypothesized relationships would be found but that they would not be strong, considering that they concerned associations between early life social events and situations and health measurements which were taken from 20 to $60 \mathrm{yr}$ later. Early differential mortality could lessen the observed relationships. Also, although these early events might have an immediate and long term effect on health, the intervening years would permit the occurrence of other events and situations with a frequency proportionate to the period of time. These might have similar inherent impact but 
TABLE 11. SigNIFICANCE OF THE RELATIONSHIPS BETWEen RISK FACTORS AND PARENTAL STATUS INCONGRUENCY MEASURES BY SEX AND AGE ${ }^{(a)}$

\begin{tabular}{|c|c|c|c|c|c|c|}
\hline \multirow{3}{*}{$\begin{array}{l}\text { Risk factors } \\
\text { and sex }\end{array}$} & \multicolumn{6}{|c|}{ Parental status incongruency measures and age } \\
\hline & \multicolumn{2}{|c|}{$\begin{array}{l}\text { Father's education- } \\
\text { father's occupation }\end{array}$} & \multicolumn{2}{|c|}{$\begin{array}{l}\text { Mother's education- } \\
\text { father's occupation }\end{array}$} & \multicolumn{2}{|c|}{$\begin{array}{l}\text { Mother's education } \\
\text { father's education }\end{array}$} \\
\hline & $35-49$ & $50-69$ & $35-49$ & $50-69$ & $35-49$ & $50-69$ \\
\hline \multicolumn{7}{|l|}{ Blood pressure, systolic } \\
\hline Males & 0 & 0 & 0 & 0 & 0 & 0 \\
\hline Females & 0 & 0 & () & 0 & $\left(\ddagger^{* * * *}\right)$ & 0 \\
\hline \multicolumn{7}{|l|}{$\begin{array}{l}\text { Blood pressure, } \\
\text { diastolic 5th phase }\end{array}$} \\
\hline Males & 0 & 0 & 0 & 0 & 0 & 0 \\
\hline Females & $\left(+^{*}\right)$ & $\left(\begin{array}{l}+* \\
+\end{array}\right)$ & 0 & 0 & $\left(\ddagger^{* *}\right)$ & 0 \\
\hline \multicolumn{7}{|l|}{ Blood glucose score } \\
\hline Males & 0 & 0 & 0 & 0 & 0 & 0 \\
\hline Females & $\left(\begin{array}{l}+* \\
+\end{array}\right)$ & 0 & 0 & 0 & $\left(f^{*}\right)$ & 0 \\
\hline \multicolumn{7}{|l|}{ Serum cholesterol } \\
\hline Males & 0 & 0 & $t^{*}$ & 0 & $\left(t^{* *}\right)$ & 0 \\
\hline Females & 0 & 0 & 0 & 0 & 0 & 0 \\
\hline \multicolumn{7}{|l|}{ Serum uric acid score } \\
\hline Males & 0 & 0 & 0 & $t^{* *}$ & 0 & 0 \\
\hline Fcmales & $\left(\ddagger^{* *}\right)$ & 0 & 0 & 0 & 0 & 0 \\
\hline \multicolumn{7}{|l|}{ F.E.V.1.0 score } \\
\hline Males & 0 & 0 & 0 & 0 & 0 & 0 \\
\hline Females & $\dagger^{* * *}$ & 0 & 0 & 0 & 0 & 0 \\
\hline \multicolumn{7}{|l|}{ Adiposity index } \\
\hline Males & 0 & 0 & 0 & 0 & 0 & 0 \\
\hline Females & $\left(\ddagger^{*}\right)$ & 0 & 0 & 0 & 0 & 0 \\
\hline \multicolumn{7}{|l|}{$\begin{array}{l}\text { No. cigarettes smoked } \\
\text { currently }\end{array}$} \\
\hline Males & $\left(\ddagger^{*}\right)$ & 0 & $(+* *)$ & 0 & 0 & 0 \\
\hline Females & 0 & 0 & 0 & 0 & 0 & 0 \\
\hline \multicolumn{7}{|l|}{$\begin{array}{l}\text { No. units alcohol } \\
\text { consumed currently }\end{array}$} \\
\hline Males & 0 & 0 & 0 & 0 & 0 & 0 \\
\hline Females & $\dagger * * *$ & $\dagger^{* * * *}$ & $\dagger^{* *}$ & 0 & 0 & 0 \\
\hline
\end{tabular}

(a) Within each sex-age group, the means of the congruent and incongruent for each health variable were compared by one-way analysis of variance. Significance was determined by the $F$ test.

fIndicates a significant relationship in the hypothesized direction; i.e. the incongruent have a higher mean for all variables except F.E.V.; the incongruent have a lower mean for F.E.V.

$¥$ Indicates a large difference in the opposite direction.

$* P \leq 0.10: * * P \leq 0.05:{ }^{* *} P \leq 0.01$.

would also likely be involved in many interactions among the existing psychosocial and physiologic factors. These other variables would tend to mediate the effects of the early variables and possibly ameliorate them. Health measurements closer in time to the occurrence of the social events might or might not allow a more direct measure of the association among them; however, the hypotheses in this study were deliberately concerned with long term effects or relationships.

The findings evaluated in this context are that, for women, aspects of childhood geographic mobility appear to have a relationship to health status that withstood the test of timc. Mobility among men either did not withstand the time test or never was associated with health status. Obviously, it cannot be said from this study which alternative is true. The lack of significant relationships, or even a 
TABle 12. SignifiCANCE OF THE RELATIONSHIPS BETWEEN CATEGORIZED HEALTH CHARACTERISTICS AND PARENTAL STATUS INCONGRUENCY MEASURES BY SEX AND AGE

\begin{tabular}{|c|c|c|c|c|c|c|}
\hline \multirow{3}{*}{$\begin{array}{l}\text { Categorized health } \\
\text { characteristics } \\
\text { and sex }\end{array}$} & \multicolumn{6}{|c|}{ Parental status incongruency measures and age } \\
\hline & \multicolumn{2}{|c|}{$\begin{array}{l}\text { Father's education- } \\
\text { father's occupation }\end{array}$} & \multicolumn{2}{|c|}{$\begin{array}{l}\text { Mother's education- } \\
\text { father's occupation }\end{array}$} & \multicolumn{2}{|c|}{$\begin{array}{l}\text { Mother's education- } \\
\text { father's education }\end{array}$} \\
\hline & 3549 & $50-69$ & $35-49$ & $50-69$ & $35-49$ & $50-69$ \\
\hline \multicolumn{7}{|l|}{ Deceased } \\
\hline Males & 0 & 0 & 0 & $\dagger * *$ & 0 & 0 \\
\hline Females & 0 & 0 & 0 & 0 & 0 & $+*$ \\
\hline \multicolumn{7}{|l|}{ CHD } \\
\hline Males & 0 & 0 & 0 & 0 & $(\stackrel{+* *}{+*})$ & 0 \\
\hline Females & 0 & 0 & 0 & 0 & 0 & $\left(\ddagger^{*}\right)$ \\
\hline \multicolumn{7}{|l|}{ Hypertension } \\
\hline Males & 0 & $\left(\ddagger^{*}\right)$ & $\left(\ddagger^{* *}\right)$ & 0 & 0 & 0 \\
\hline Females & 0 & 0 & 0 & 0 & 0 & 0 \\
\hline \multicolumn{7}{|l|}{ Diabetes } \\
\hline Males & 0 & 0 & 0 & $\dagger * * *$ & 0 & $\dagger * *$ \\
\hline Females & 0 & 0 & 0 & 0 & 0 & 0 \\
\hline \multicolumn{7}{|l|}{ Chronic bronchitis } \\
\hline Males & $(+* * *)$ & 0 & 0 & 0 & 0 & 0 \\
\hline Females & 0 & $\dagger * *$ & $\left(t^{*}\right)$ & 0 & 0 & 0 \\
\hline \multicolumn{7}{|l|}{ Asthma } \\
\hline Males & 0 & 0 & $\left(t^{*}\right)$ & 0 & 0 & 0 \\
\hline Females & 0 & $\left(\begin{array}{l}+* * \\
+\end{array}\right)$ & 0 & 0 & 0 & 0 \\
\hline \multicolumn{7}{|l|}{ Cigarette smokers } \\
\hline Males & $(\stackrel{*}{*})$ & 0 & $\left(\ddagger^{*}\right)$ & 0 & 0 & 0 \\
\hline Females & 0 & 0 & 0 & 0 & 0 & 0 \\
\hline \multicolumn{7}{|l|}{ Alcohol drinkers } \\
\hline Males & 0 & 0 & 0 & 0 & 0 & 0 \\
\hline Females & 0 & 0 & 0 & 0 & 0 & $\left(\ddagger^{*}\right)$ \\
\hline \multicolumn{7}{|l|}{$\begin{array}{l}\text { No. of chronic } \\
\text { conditions }\end{array}$} \\
\hline Males & 0 & 0 & 0 & 0 & 0 & 0 \\
\hline Females & $(* *)^{a}$ & 0 & 0 & 0 & **a & 0 \\
\hline
\end{tabular}

(a) A significant chi-square was obtained for younger men for father's education-occupation for number of chronic conditions, but the relationship was not as predicted. For mother's-father's education a significant chi-square was obtained in partial substantiation of the hypothesis of aggregation of disease among the incongruent.

HIndicates a significant relationship in the hypothesized direction; i.e. more of the incongruent have the poor health characteristic.

Indicates a large difference in the opposite direction.

$* P \leq 0.10 ;{ }^{* *} P \leq 0.05 ; * * P \leq 001$

tendency in that direction, between the other two sets of social variables and health status also may not be attributed to either time or no original effect.

The operational definitions of mobility used in this study differ in kind and number from those reported by other investigators relating health to residential moves $[24,25,28]$. Some have used one measure, as cross county moves; others, a change of address from one interviewing period to another; and others, number of moves during childhood and adulthood. Although these studies investigated the same general hypothesis, the stressful effects of moving on health, considering the different operational definitions and the different periods of life referred to, it is not surprising that the findings are not the same from study to study. As described earlier, this study's 5 mobility measures attempted to measure at least 
5 different apparent meanings of the concept and the index attempted to measure a composite of mobility. Many of these separate measures were obviously intercorrelated by definition, and, in this population, interrelated otherwise. Nevertheless, the values were not high enough even between the most highly related so that the variance of one accounted for more than half the variance of any other. The interrelationships, therefore, did not preclude the different meanings for these measures. The differences in the relationships between these separate measures and many of the dependent health variables appear to substantiate the differences in their meanings. The lack of consistent relationship between the index and the dependent variables indicates that no greater understanding is provided either by this composite or by a simple additive index.

All of these different aspects of mobility were associated with the prevalence of CIID among older women. The lack of existence of a similar association among younger women may be due to the fact that this condition does not usually manifest itself until a later age. All five measures of mobility were related to cigarette smoking (categorical) among younger women but only two measures of mobility were so related for older women. These two were dissimilarity of size and fewer number of years lived in small communities, and they share the common theme of proportion of childhood in similar environments. The underlying meaning could be amount of exposure to small town characteristics, regardless of number of moves within that environment.

The pattern for alcohol drinking (categorical-never or ever), an arguable risk factor if consumption is low, largely followed that for cigarette smoking. Thus, among younger women, more of whom smoke than older women, more tried smoking and continued to do so if they moved about in childhood and if they were exposed to a variety of environments represented by different community sizes. Among the older women, more currently smoked or had in the past, only if they have been exposed to a variety of community sizes. One question that arises is whether the association is due to stress induced by the moves or to exposure to the variety of permissible social options provided by the variety of environments, or to both.

Mobility among men was not related to the health measures, a finding counter to that of Syme's [24] but similar to that of Wardwell's [25]. In both studies, residential mobility was part of a larger measure of 'cultural mobility,' with the Syme study covering mobility in adulthood and the Wardwell study covering mobility in childhood and adulthood in separate analyses. The reasons for the difference between men and women in this study are not known yet, but one explanation may be found in a frequently suggested hypothesis that women are more socially sensitive to interpersonal relationships perhaps because of the requirements of their roles as mothers and wives. Also, it may be that women retain the effects of early social events over longer periods of time because they have less of a variety of role demands made on them over time. That is, men are expected to deal with the variety of demands made by roles of husbands, fathers, workers, citizens and friends, whereas the older women, at least, and in small communities, have not generally been expected to concern themselves with the roles of workers and citizens. Cassel has also suggested another provocative explanation recently in a discussion of the effects of domination and subordination mediating social pro- 
cesses in animal experiments when he stated "that studies aimed at identifying the health consequences of migration should distinguish those migrants who occupy subordinate positions in their host countries from those who occupy positions of power and prestige" [1].

The lack of significant or suggestive relationships, as hypothesized, between parental deprivation and health status was most interesting in view of the expectation that this social variable would be the most influential of the three studied. It is possible that the single measure was too crude. For example, the analysis did not differentiate either those respondents who lived in a one parent situation, natural or surrogate; nor those who lived in a two parent situation where one or both parents were surrogates. It also did not compare those whose one parent situation was as 'adequate' or more so than those who had two natural parents. The analytic distinction was made on the absence of at least one natural parent and for periods of time ranging from 1 to $17 \mathrm{yr}$. The length of the period of deprivation had no consistent relationships with the health variables, as hypothesized or otherwise. The findings of this study, therefore, do not agree with those reviewed by Chen and Cobb [29].

The data from this study also did not substantiate the hypothesis, for either men or women, that parental status incongruence, as defined here by the separate measures or the index, would be related to measures of poor health status. This finding differs from that found by Kasl and Cobb in their study of rhcumatoid arthritis, a measure of poor health status not included in this analysis [26]. The expected set of relationships were based on the rationale that parental status incongruence would be associated with conflicting expectations of behavior among the family members. The familial environment would then likely be characterized by tension and this would have a detrimental effect on the health and health habits of the children so exposed. Of course, other family dynamics can be postulated in a status incongruent situation. The parental expectations do not have to be in conflict, but may align with the highest status present, particularly with respect to educational achievement. Also the dominant expectations may be those associated with the status of the parent whose relatives were closest physically and seen most often, lending continuous reinforcement. Also conceivable is the proposition that status difference as measured by education and occupation is not as important in this small community as it would be in larger communities where the social differences and their material attributes may be greater.

\section{REFERENCES}

1. Cassel J: An epidemiological perspective of psychosocial factors in disease etiology. Am $\mathbf{J}$ Publ Hlth 64: 1040-1043, 1974

2. Smith T: Factors involving sociocultural incongruity and change: A review of empirical findings. Milbank Memorial Fund Quart 45(2): 23-39, 1967

3. Marks RU: Factors involving social and demographic characteristics: A review of empirical findings. Milbank Memorial Fund Quart 45(2): 51-108, 1967

4. Cafrey B: Factors involving interpersonal and psychological characteristics: A review of empirical findings. Milbank Memorial Fund Quart 45(2): 119-139, 1967

5. Lehman EW: Social class and coronary heart disease: A sociological assessment of the medical literature. J Chron Dis 20: 381-391, 1967

6. Jenkins CD: Psychologic and social precursors of coronary disease. New Engl J Med 284: 244-255, 307-317, 1971

7. Antonovsky A: Social class and the major cardiovascular diseases. J Chron Dis 21: 65-106, 1968 
8. House J: Occupational stress and coronary heart disease: A review and theoretical integration. J Hlth Soc Behav 15: 12-27, 1974

9. National Workshop Conference on Socioenvironmental Stress and Cardiovascular Disease. Phoenix Arizona, 14-16 February, 1966. Published in Social Stress and Cardiovascular Disease, Milbank Memorial Fund Quart 45(2), 1967

10. Conference on Stressful Life Events: Their nature and effects, New York City, New York, 1973. In: Stressful Life Events: Their Nature and Effects. Dohrenwend BS, Dohrenwend BP (Eds). New York: John Wiley, 1974

11. Bahnson CB: Epistemological perspectives of physical disease from the psychodynamic point of view. Am J Publ Hith 64: 1034-1040, 1974

12. Rosenman RH, Friedman $M$ et al:: A predictive study of coronary heart disease: The Western Collaborative Group Study. J Am Med Ass 189: 15-22, 1964

13. Rosenman RH. Friedman $M$ et al: Coronary heart disease in the Western Collaborative Group Study: A follow-up experience of $4 \frac{1}{2}$ years. J Chron Dis 23: 173 190. 1970

14. Christenson WN, Hinkle LE: Differences in illness and prognostic signs in two groups of young men J Am Med Ass 177: 247-253, 1961

15. Rahe RH: Life crisis and health change. In: Psychotropic Drug Response: Advances in Prediction. May PRA. Wittenborn JR (Eds). pp. 92-125. Springfield, Illinois: Charles C. Thomas, 1969

16. Rahe RH, Arthur RJ: Life-change patterns surrounding illness experience. J Psychos Res 11: $341-345,1968$

17. Syme SL: Behavioral factors associated with the etiology of physical disease: A social epidemiological approach. Am J Publ Hlth 64: 1043-1049. 1974

18. Epstein FH, Napier JA, Block WD, Hayner NS, Higgins MW, Johnson BC, Keller JB, Metzner HL. Montoyc JH, Ostrander LD, Jr, Ullman BM (The senior research colleagues of the late Dr. Thomas Francis, Jr): The Tecumseh Study: design, progress and perspectives. Arch Env Hlth 21: $402-407,1970$

19. Napier JA, Johnson BC, Epstein FH: The Tecumseh Community Health Study. In: Casebook of Community Studies. Kessler 11, Leven ML (Eds). pp. 25 46. Baltimore: Johns Hopkins Press. 1970.

20. Hayner NS, Kjelsberg MO, Epstein FH. Francis J Jr: Carbohydrate tolerance and diabetes in a total community. Tecumseh, Michigan 1. Effects of age. sex and test conditions on a one hour glucose tolerance in adults. Diabetes 14: 413-423, 1965

21. Dodge HJ, Mikkelsen WM: Observations on the distribution of serum uric acid levels in participants of the Tecumseh, Michigan, Community Health Studies: A comparison of results of one method used at two different times and of two methods used simultaneously. J Chron Dis 23: 161-172. 1970

22. Higgins MW. Keller JB: Seven measures of ventilatory lung function. Population values and a comparison of their ability to discriminate between persons with and without chronic respiratory symptons and disease, Tecumseh, Michigan. Am Rev Resp Dis 108: 258-272, 1973

23. Broder I, Higgins MW, Mathews KP, Keller JB: Epidemiology of asthma and allergic rhinitis in a total community, Tecumseh, Michigan IV. Natural history. J Allergy Clin Immunol 54 100-110, 1974

24. Syme SL, Hyman MM, Enterline PE: Some social and cultural factors associated with the occurrence of coronary heart disease. J Chron Dis 17: 277-289, 1964

25. Wardwell WI. Bahnson CB: Behavioral variables and myocardial infarction in the Southeastern Connecticut Heart Study. J Chron Dis 26: 447-461, 1973

26. Kasl SV, Cobb S: Intrafamilial transmission of rheumatoid arthritis-VI. Association of rheumatoid arthritis with several types of status inconsistency. J Chron Dis 22: 259-278, 1969

27. Shekelle RB, Ostfeld AM, Paul O: Social status and incidence of coronary heart disease. J Chron Dis 22: 381 394. 1969

28. Kantor MB: Some consequences of residential and social mobility for the adjustment of children. In: Mobility and Mental Health. Kantor MB (Ed). pp. 86-122. Springfield, Illinois: Charles $C$ Thomas. 1965

29. Chen E, Cobb S: Family structure in relation to health and disease. A review of the literature. J Chron Dis 12: 544-567, 1960 